\title{
Metal and flavonol contents of Moringa oleifera grown in South Africa
}

AUTHORS:

Vusumzi Pakade ${ }^{1}$

Ewa Cukrowska ${ }^{1}$

Luke Chimuka ${ }^{1}$

\section{AFFILIATION:}

${ }^{1}$ Molecular Sciences Institute, School of Chemistry, University of the Witwatersrand, Johannesburg, South Africa

\section{CORRESPONDENCE TO:} Luke Chimuka

EMAIL:

luke.chimuka@wits.ac.za

POSTAL ADDRESS:

Molecular Sciences Institute, School of Chemistry, University of the Witwatersrand, Private Bag 3, WITS 2050, Johannesburg, South Africa

DATES:

Received: 07 July 2011

Revised: 07 Feb. 2012

Accepted: 28 Aug. 2012

\section{KEYWORDS:}

metal content; Moringa oleifera; myricetin; kaempferol; quercetin; vegetables

\section{HOW TO CITE:}

Pakade V, Cukrowska E, Chimuka L. Metal and flavonol contents of Moringa oleifera grown in South Africa. S Afr J Sci. 2013;109(3/4), Art. \#835, 7 pages. http://dx.doi. org/10.1590/sajs.2013/835

(C) 2013. The Authors. Published under a Creative Commons Attribution Licence.
Moringa (Moringa oleifera) is a plant that is commonly consumed as a nutritional supplement by some communities in South Africa. Contamination of moringa with toxic heavy metals could be deadly for consumers. However, some metal elements are essential for consumers in trace amounts. We therefore investigated the concentrations of heavy metals, including major and trace nutrient elements, in the soil and in the leaves and flowers of moringa grown on two farms in South Africa. After total digestion in the microwave, the concentrations of metals were determined using inductively coupled plasma optical emission spectroscopy. No toxic heavy metals were detected in the leaves and flowers of moringa. On average, moringa contained higher concentrations of $\mathrm{Ca}(18500 \mathrm{mg} / \mathrm{kg})$ and $\mathrm{Mg}(5500 \mathrm{mg} / \mathrm{kg})$ than selected vegetables (spinach, cabbage, cauliflower, broccoli and peas). The concentrations of other major nutrients in moringa were similar to those of the vegetables. Based on reports of antioxidant activity, we also investigated the concentrations of flavonols (myricetin, quercetin, kaempferol) in moringa leaves and flowers in comparison with the selected vegetables. A high concentration of flavonols is related to antioxidant activity. Plant and vegetable materials were extracted under reflux using an acidified methanol $(1 \% \mathrm{HCl})$ solution and the flavonols were identified and quantified using reverse-phased high-performance liquid chromatography with UV detection. Moringa leaves had higher concentrations of myricetin $(1296.6 \mathrm{mg} / \mathrm{kg})$, quercetin $(1362.6 \mathrm{mg} / \mathrm{kg})$ and kaempferol $(1933.7 \mathrm{mg} / \mathrm{kg}$ ) than vegetables (spinach: myricetin $620.0 \mathrm{mg} / \mathrm{kg}$, quercetin $17.9 \mathrm{mg} / \mathrm{kg}$, kaempferol $215.3 \mathrm{mg} / \mathrm{kg}$ ). No major differences were found between the plants growing on the two farms. Moringa is thus nutritionally valuable and safe to consume.

\section{Introduction}

Moringa oleifera Lam (Moringaceae) is one of 14 species of genus Moringa and is the most common species in the genus. The first discoveries of the moringa tree can be traced back to India, Asia and some parts of Western Africa. ${ }^{1}$ In Africa, Ghana, Senegal and Malawi have the highest production of moringa. South African farmers have also shown an interest in the plant and a few have started growing it. To date, the plant has had various uses, including medicinal, nutritional and industrial (such as the removal of toxic heavy metals from wastewater and in animal feed).$^{2-4}$ It has been shown that the leaves, flowers and fruits of moringa are more important nutritionally, whereas the roots, stem, wood and bark are known for their medicinal value (with stimulant, aphrodisiac, diuretic and cholagogic properties) ${ }^{5,6}$ The leaves of moringa are known to be rich in different forms of phytochemicals ${ }^{7,8}$ as well as nitriles, thiocarbamates and carbamates, with strong hypotensive and spasmolytic effects. ${ }^{9}$ Epidemiological studies have shown that foods rich in antioxidants may provide protection against degenerative diseases such as coronary heart disease, cancer and Alzheimer's disease. ${ }^{10-12}$ Free radicals in our bodies can kill cells, inactivate enzymes and degrade DNA and cell membranes. ${ }^{13}$ Therefore, a high intake of antioxidants from dietary sources is very important as these compounds remove the free radicals in our bodies. ${ }^{14}$ It has also been shown that natural antioxidants are better than synthetic antioxidants as they are less toxic and more potent. ${ }^{15,16}$ Various forms of natural antioxidants in plants include flavonoids, tocopherols, vitamin $\mathrm{C}$ and phenolic compounds. ${ }^{17}$ Moringa has emerged as one of the plants which contain high concentrations of flavonoids; these compounds have been shown to be well distributed in the plant as they are found in leaves, flowering tissues and pollens. ${ }^{18}$

Although moringa can tolerate a wide range of rainfall and soil conditions and is drought resistant, ${ }^{19}$ these agroclimatic conditions can influence the nutrient and flavonol contents in the plant. In a report by Siddhuraju and $B^{B e c k e r}{ }^{5}$, it was clearly shown that the antioxidant activities of moringa leaves from different countries varied widely. However, no South African plants were included in the study. Knowledge of the contents and effects of moringa grown in South Africa will be beneficial to those who consume the plants, as well as for product development of moringa extracts.

Moringa is used mainly by disadvantaged communities as a nutritional supplement in their daily diets, and so it is important to know the nutritional benefits of moringa. As well as nutritional benefits, it is also important to determine any detrimental effects of moringa consumption, such as heavy metal toxicity.

Heavy metal pollution of soil is a worldwide phenomenon. There are several sources of these metals, including mining activities, smelting, coal burning, urban compost, paint pigment and battery manufacturing, municipal wastewater sludge, leather tanning, metal finishing, phosphate fertilisers, atmospheric deposition and pesticides. ${ }^{20,21}$ In fact, soil is known to act as a reservoir for these heavy metals. ${ }^{22}$ However, there are also other natural sources of heavy metals. Unlike organic compounds, inorganics are not degradable, which means they have longer half-lives in both terrestrial and aquatic environments. When these heavy metals are present in higher concentrations than is recommended, they become toxic to the ecosystem and, eventually, to humans ${ }^{23}$ because the plants which are consumed by humans may accumulate these heavy metals. However, some of the elements, in trace amounts, are needed as they play an important role in biological, chemical, enzymatic, and metabolic reactions in the living cells of plants, animals and humans. ${ }^{24}$ For example, minor nutrients such as iron, zinc and chromium are essential for the human body. Iron is present in two forms - haem and non-haem. Usually haem is found in red meat and 
chicken meat, whereas non-haem is found in green leafy vegetables. ${ }^{25}$ Of the two forms, haem is more easily absorbed by the body. Analysis of these trace nutrients in moringa is therefore also of interest.

The aims of our study were therefore to evaluate both heavy metals and metal nutrients in the soils in which moringa were planted as well as in the plant itself. We investigated the heavy metal contents of moringa plants, as well as the soil in which they were planted, on two farms in South Africa - in Atteridgeville in Gauteng, a highly industrialised region, ${ }^{26}$ and in a rural village known as a Tooseng in the Limpopo Province. To indicate the antioxidant properties of moringa, we also investigated the flavonol contents. Metal nutrient and flavonol contents of the plant were then compared with those of commonly consumed vegetables. To our knowledge, no such study has been undertaken in South Africa.

\section{Materials and methods}

\section{Chemicals and reagents}

Quercetin, kaempferol, myricetin, methanol (HPLC grade), formic acid, nitric acid and hydrogen peroxide were all purchased from Sigma Aldrich (Johannesburg, South Africa). Stock solutions of quercetin $(0.3 \mathrm{~g} / \mathrm{L})$, kaempferol $(50 \mu \mathrm{g} / \mathrm{mL})$ and myricetin $(50 \mu \mathrm{g} / \mathrm{mL})$ in methanol and $1 \%$ formic acid were prepared in the laboratory and kept at $-18^{\circ} \mathrm{C}$ when not in use. Ultrapure water (Milli-Q, Billerica, MA, USA) was used in all experiments and chemicals were used as received. The structures of flavonols analysed are given in Figure 1.

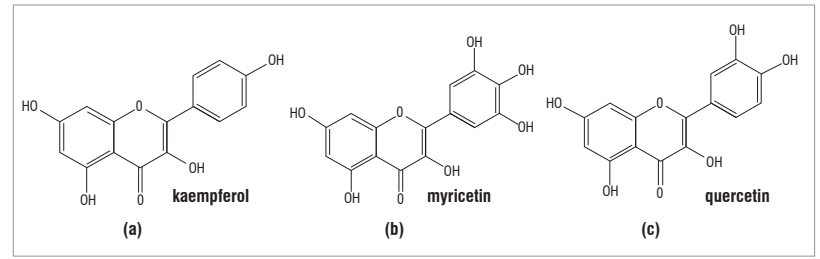

Figure 1: Chemical structures of (a) kaempferol, (b) myricetin and (c) quercetin.

\section{Instrumentation}

A high-performance liquid chromatography (HPLC)-UV, SRI 210D (LoS Angeles, CA, USA) equipped with a UV/Vis detector (VUV-24) and a Phenomenex $C_{18}$ column ( $\left.150 \times 4.6 \mathrm{~mm}, 5 \mu \mathrm{m}\right)$ was used for the identification and quantification of flavonols from methanolic extracts. Metal content was analysed using inductively coupled plasma optical emission spectroscopy (ICP-OES) (Spectro Genesis, Spectro, Germany).

\section{Preparation of samples}

\section{Leaf samples}

Fresh M. oleifera leaves were collected in April 2011 from two growing areas (Tooseng, Limpopo and Atteridgeville, Gauteng) in South Africa. A total of four moringa leaf samples were investigated. The leaf samples were labelled 2006LF, 2009LF, 2010LF and 2010AF. The number denotes the year in which the tree was planted and LF and AF stand for the farms in Limpopo and in Atteridgeville, respectively. The leaves were immersed in a container of deionised water for $1 \mathrm{~min}$ to remove surface contaminants. The leaves were then lyophilised for a few days. After freeze drying, the samples were homogenised and ground into a fine powder and kept in the dark in a cool place until further use. Moringa flowers were processed in the same way but were collected only from 2010LF trees.

\section{Vegetable samples}

Vegetables commonly consumed by South Africans (spinach, cabbage, peas, cauliflower and broccoli) were bought from a local supermarket in Gauteng. The inedible parts were removed with a sharp steel knife. Then, about $1.0 \mathrm{~kg}$ of the edible part of each vegetable sample was washed with tap water. A sharp knife was used to cut the washed parts into small pieces of approximately $1 \times 1 \mathrm{~cm}$. The vegetable samples were then processed in the same manner described above for the moringa leaves.

\section{Soil samples}

Soil samples were collected from adjacent to the trunk of the tree from which the leaves were collected and were labelled clearly to correspond with the leaf samples. A spade was used to dig to a depth of about $10-15 \mathrm{~cm}$ next to the plant roots and the soil within this area was collected. The soil was air dried, homogenised and passed through a $1-\mathrm{mm}$ sieve to remove big particles and stones. The soil samples were then milled to a fine powder using a commercial pulveriser (Fritsch pulverisette 6, Fritsch $\mathrm{GmbH}$, Idar-Oberstein, Germany).

\section{Determination of dry matter}

For dry matter determination, about $3 \mathrm{~g}$ of freeze-dried leaf samples (in triplicate) were dried in an electric drying oven (Labotec Model 321, Umhlanga, South Africa) at $70{ }^{\circ} \mathrm{C}$ for 3 days until a constant mass was achieved.

\section{Total digestion}

A mass of $0.1 \mathrm{~g}$ of freeze-dried leaf sample was placed in a microwave digestion vessel. To this was added $8 \mathrm{~mL}$ concentrated nitric acid and $2 \mathrm{~mL}$ hydrogen peroxide. Digestion was carried out for about $30 \mathrm{~min}$ in the microwave. After digestion, the sample was transferred to a $25-\mathrm{mL}$ volumetric flask and made up to volume with deionised water. The solutions were directly analysed for metal content using ICP-OES. All digestions were carried out in triplicate.

A similar protocol was followed for total digestion of the soil samples. A mass of $0.1 \mathrm{~g}$ of dried soil sample was placed in a microwave digestion vessel. However, $6 \mathrm{~mL}$ of concentrated hydrochloric acid, $2 \mathrm{~mL}$ concentrated nitric acid and $1 \mathrm{~mL}$ hydrofluoric acid was added to the vessel. When the digestion was finished (after about $50 \mathrm{~min}$ ), $6 \mathrm{~mL}$ boric acid was added to each vessel to neutralise the hydrofluoric acid. The solutions were transferred into $25-\mathrm{mL}$ volumetric flasks and made up to volume with deionised water. All solutions were measured for metal content using ICP-OES. All digestions were carried out in triplicate.

\section{Extraction and hydrolysis of flavonols}

Extraction and hydrolysis of flavonols were carried out using the method of Sultana and Anwar ${ }^{27}$ with slight modifications. Briefly, $100 \mathrm{~mL}$ of acidified methanol containing $1 \%(\mathrm{v} / \mathrm{v}) \mathrm{HCl}$ was added to $5 \mathrm{~g}$ freeze-dried leaves contained in a $250-\mathrm{mL}$ round-bottomed flask. The flask was fitted with a reflux condenser. To this flask was added $20 \mathrm{~mL}$ of $1.2 \mathrm{M} \mathrm{HCl}$ and the mixture was heated at $90^{\circ} \mathrm{C}$ for $14 \mathrm{~h}$ to obtain aglycons of flavonols and some phenolic acids. The extract was cooled to room temperature and then sonicated for $5 \mathrm{~min}$ to remove air and filtered through Whatman filter paper. Finally, the extract to be used for direct injection for HPLC was further filtered through a $0.45-\mu \mathrm{m}$ filter paper (Millipore, Bedford, MA, USA). When not in use, the extract solution was stored at $-18^{\circ} \mathrm{C}$.

\section{Quantification of flavonols}

A methanol:water solution (45:55) containing formic acid (0.13 M, 1.0 vol\%) was used as a mobile phase. The flow rate was $1 \mathrm{~mL} / \mathrm{min}$. A column oven temperature was maintained at $40^{\circ} \mathrm{C}$. The injection volume was $20 \mu \mathrm{L}$ and detection of myricetin, quercetin and kaempferol was accomplished at $370 \mathrm{~nm}$. Quantification of quercetin and all other compounds tested was performed using a five-point calibration curve of standards at concentrations between $0.5 \mu \mathrm{g} / \mathrm{mL}$ and $20 \mu \mathrm{g} / \mathrm{mL}$.

\section{Results and discussion}

\section{Flavonols in moringa grown in South Africa}

The flavonol content of Moringa oleifera leaves is reported as the concentration of quercetin, myricetin and kaempferol in Table 1. Table 1 
shows that the sample of moringa leaves taken from plants grown since 2009 had the highest concentration of flavonols $(5121.9 \mathrm{mg} / \mathrm{kg})$. This concentration is closely followed by the 2010 sample which had a total concentration of $4535.7 \mathrm{mg} / \mathrm{kg}$. The 2006 sample had the lowest concentration of total flavonols $(4447.1 \mathrm{mg} / \mathrm{kg})$. However, looking at individual concentrations of the three different flavonols assayed from these plant samples, the 2009 sample had the highest concentrations of quercetin $(1972.8 \mathrm{mg} / \mathrm{kg})$ and kaempferol $(2145.2 \mathrm{mg} / \mathrm{kg})$. Myricetin ranged from $1004 \mathrm{mg} / \mathrm{kg}$ to $1809 \mathrm{mg} / \mathrm{kg}$. Interestingly, the total flavonol content in our samples was comparable to that obtained by Sultana and Anwar $^{27}(6125.6 \mathrm{mg} / \mathrm{kg})$ for moringa grown in Pakistan. However, the distribution of flavonols differs, as Sultana and Anwar found that the moringa in Pakistan contained $5804.4 \mathrm{mg} / \mathrm{kg}$ myricetin, $281.0 \mathrm{mg} / \mathrm{kg}$ quercetin and $40.2 \mathrm{mg} / \mathrm{kg}$ kaempferol. The three flavonols - kaempferol, quercetin, and myricetin - were investigated in detail and found to reduce the risk of pancreatic cancer by $23 \%{ }^{28}$ and are thus very important nutritionally.

Table 1: Concentration of flavonols ( $\mathrm{mg} / \mathrm{kg}$ dry matter) in Moringa oleifera and selected vegetable samples

\begin{tabular}{|c|c|c|c|c|}
\hline Sample & Myricetin & Quercetin & Kaempferol & Total flavonols \\
\hline \multicolumn{5}{|l|}{ Vegetables } \\
\hline Cabbage & nd & nd & nd & nd \\
\hline Spinach & $620.0( \pm 5.1)$ & $17.9( \pm 0.1)$ & $215.3( \pm 0.3)$ & $853.1( \pm 2.3)$ \\
\hline Peas & nd & nd & nd & nd \\
\hline Cauliflower & nd & nd & nd & nd \\
\hline Broccoli & nd & nd & nd & nd \\
\hline \multicolumn{5}{|c|}{ Moringa leaves } \\
\hline $2006 \mathrm{LF}$ & $1443.3( \pm 12.5)$ & $1084.7( \pm 4.2)$ & $1919.1( \pm 3.5)$ & $4447.1( \pm 4.5)$ \\
\hline 2009LF & $1004.0( \pm 8.5)$ & $1972.8( \pm 2.1)$ & $2145.2( \pm 3.3)$ & $5121.9( \pm 3.7)$ \\
\hline 2010LF & $1809.1( \pm 2.4)$ & $1097.1( \pm 1.1)$ & $1629.5( \pm 3.4)$ & $4535.7( \pm 2.6)$ \\
\hline $2010 \mathrm{AF}$ & $929.8( \pm 12.6)$ & $1295.6( \pm 10.7)$ & $2040.8( \pm 11.8)$ & $4266.1( \pm 5.9)$ \\
\hline $\begin{array}{l}\text { Moringa } \\
\text { flowers }\end{array}$ & $27.6( \pm 11.3)$ & $4244.6( \pm 5.2)$ & $6535.8( \pm 3.9)$ & $10807.9( \pm 4.5)$ \\
\hline
\end{tabular}

$n d$, not detected

$A F$, farm in Atteridgeville; LF, farm in Limpopo. Years denote when the plants were planted.

Error bars are $\pm R S D$

In a study by Siddhuraju and Becker ${ }^{5}$, it was reported that the quercetin concentration of $M$. Oleifera leaves ranged from $634 \mathrm{mg} / 100 \mathrm{~g}$ to $2749 \mathrm{mg} / 100 \mathrm{~g}$ while kaempferol levels ranged from $105 \mathrm{mg} / 100 \mathrm{~g}$ to $647 \mathrm{mg} / 100 \mathrm{~g}$. It is clear that the quercetin levels obtained in Siddhuraju and Becker's study were higher than those obtained in the present study, whilst kaempferol levels were similar to those of the present study at about $1200 \mathrm{mg} / \mathrm{kg}$. Such differences are largely attributed to factors such as agroclimatic region, post-harvest handling, genetic variability and stage of leaf development. ${ }^{5,29}$ It was shown in the same study ${ }^{5}$ that flavonol contents of samples obtained from India, Niger and Nicaragua were different.

A typical calibration curve used for the quantification of the three flavonols by HPLC is shown in Figure 2. Good precision was obtained as $R^{2}$ values were close to one.

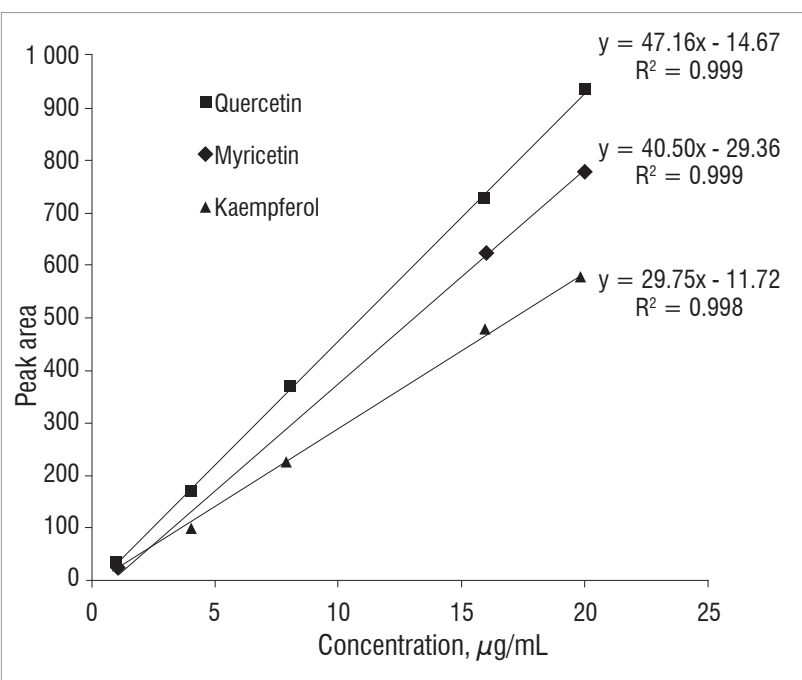

Figure 2: Typical calibration curves for flavonols.

\section{Soil properties}

In order to understand the relationship between the concentrations of metals in the soil and those in the plants grown in the soil, selected soil properties - conductivity, pH and redox potential - were investigated. The properties of the soil samples are given in Table 2.

Table 2: Properties of the soils in which the moringa plants were grown

\begin{tabular}{l|l|l|l|l}
\hline \hline Sample & $\begin{array}{l}\text { Conductivity } \\
(\mu \mathrm{S} / \mathbf{c m})\end{array}$ & $\mathbf{p H}^{\dagger}$ & $\mathbf{p H}^{\ddagger}$ & $\begin{array}{l}\text { Redox } \\
\text { potential (mV) }\end{array}$ \\
\hline \hline $2009 \mathrm{LF}$ & 26 & 7.65 & 8.03 & 281 \\
\hline $2010 \mathrm{LF}$ & 14 & 7.55 & 8.24 & 286 \\
\hline $2006 \mathrm{LF}$ & 59 & 7.86 & 7.32 & 240 \\
\hline $2010 \mathrm{AF}$ & 14 & 4.62 & 7.87 & 370 \\
\hline
\end{tabular}

$A F$, farm in Atteridgeville; LF, farm in Limpopo. Years denote when the plants were planted.

${ }^{t} \mathrm{pH}$ measured using $\mathrm{CaCl}_{2} ;{ }^{\ddagger} \mathrm{pH}$ measured using deionised water

\section{Soil pH}

The $\mathrm{pH}$ of the soils was measured using two methods. The first method involved using a suspension of soil and deionised water in a 1:2 ratio and the second involved using a suspension of soil in a solution of $\mathrm{CaCl}_{2}$ $(0.01 \mathrm{M})$ in a 1:2 ratio. ${ }^{30}$ When deionised water was used, the $\mathrm{pH}$ of the soil was found to be in the range of 7.32-8.24. Whereas when a $\mathrm{CaCl}_{2}$ solution was used, the soil pH was in the range 4.62-7.85. Because of the high $\mathrm{pH}$ level in the soil in which moringa was grown, it is possible that, to a certain extent, some trace metals were not available for plant uptake. A low pH (acidity) increases the mobility of trace metals as a result of a greater likelihood of cation exchange reactions taking place. The optimum soil pH required for moringa plant growth is 5.0-9.0. ${ }^{31}$ The soil pH values reported above are within this range.

\section{Electrical conductivity}

The electrical conductivity of soil is related to the presence of cations and anions. High electrical conductivity indicates a high concentration of ions in the soil. However, similar values of electrical conductivity between two soils do not mean that the ions present in the soil are the same. A slight variation between the soils is possible. The electrical conductivity values of the soils in this study are presented in Table 2. 
The soil obtained adjacent to the oldest plant (2006LF) had the highest electrical conductivity. The conductivity of the soil adjacent to the older plants (2006LF and 2009LF) may be higher than the soil from around the young plants because of a greater presence of nutrients and other metal ions as an older plant absorbs these from soil further away. However, the observed differences should be treated with caution because the data could not be evaluated for statistical differences. To make any conclusions regarding the effect of the age of a plant, several plants of the same age would need to be investigated.

\section{Redox potential}

The redox potential $\left(E_{h}\right)$ shows that the soils were under basic reducing conditions, which further illustrates the inability to release heavy metals to the plants..$^{32}$ This result could explain why no toxic heavy metals were detected from the moringa samples. Generally, positive $E_{h}$ values are characteristic of bottom deposits which are poor in organic matter or which are well oxygenated, whereas negative $E_{h}$ values are associated with bottom deposits which are rich in organic matter. ${ }^{33}$

\section{Metal content in soil}

Metal content of the soils in which the plants were grown was determined from total digestion solutions using ICP-OES. This analysis is important as it gives the relative concentrations of metals in the soil and in the plants. These results give an indication of whether there is a source of contamination in the soil or if the metals are just naturally abundant. Because moringa leaves are consumed by people it is imperative to know the concentration of toxic heavy metals in the soil as these metals can be taken up by the plants and cause harm, or even death, ${ }^{22}$ when consumed.

Metals found in the soil can be divided into two categories: major nutrients and trace elements. Major nutrients $(\mathrm{K}, \mathrm{Na}, \mathrm{Ca}, \mathrm{Mg}, \mathrm{P})$ are needed by both plants and humans in large quantities, whereas trace elements ( $\mathrm{Zn}, \mathrm{Mn}, \mathrm{Cu}, \mathrm{Cr}, \mathrm{Co}, \mathrm{Ni})$ are needed only in small quantities by both plants and humans. The concentrations of major nutrients and trace elements in the soils in this study are shown in Figures 3 and 4 , respectively. Polluted soil might contain toxic heavy metals such as $\mathrm{Pb}$, $\mathrm{Hg}$ or $\mathrm{U}$. These toxic heavy metals were not detected in the soil samples we analysed.

Generally, the soils from the farm in Limpopo contained higher concentrations of major nutrients than the soils from the farm in Atteridgeville (Figure 3). Soil from the farm in Limpopo contained the highest concentration of $\mathrm{K}(15000 \mathrm{mg} / \mathrm{kg})$, $\mathrm{Ca}(3200 \mathrm{mg} / \mathrm{kg})$ and $\mathrm{Mg}$ $(3000 \mathrm{mg} / \mathrm{kg})$. However, soil from the farm in Atteridgeville contained a higher concentration of $\mathrm{Na}(7000 \mathrm{mg} / \mathrm{kg})$ than soil from the Limpopo $(5800 \mathrm{mg} / \mathrm{kg})$. The concentration of Ph was similar in soils from both farms (Figure 3).

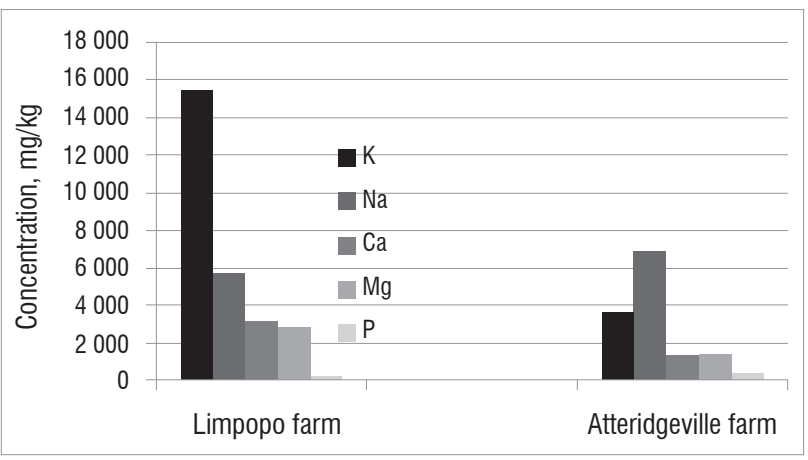

Figure 3: Average concentration of major nutrients in soil samples from farms in the Limpopo and Atteridgeville. Results shown are means of triplicates; errors bars (\%RSD) are omitted because they do not add value at this scale.

Figure 4 displays the minor nutrient elements found in soils on both farms. Samples from both farms contained high concentrations of $\mathrm{Mn}$ relative to other trace elements. The concentration of $\mathrm{Mn}$ in the soil from the farm in Limpopo was $650 \mathrm{mg} / \mathrm{kg}$, while that from the farm in Atteridgeville was $550 \mathrm{mg} / \mathrm{kg}$. Other minor elements investigated were below $100 \mathrm{mg} / \mathrm{kg}$, except the concentration of $\mathrm{Cr}$ in the soil from the Atteridgeville farm (which was about $240 \mathrm{mg} / \mathrm{kg}$ ). High concentrations of these trace metals (particularly Fe and $\mathrm{Mn}$ ) were reported by Gonzalez and Gonzalez-Chavez ${ }^{34}$ in urban soils and soils from waste dumpsites. They noted that the anthropogenic sources of these elements could not be ruled out. ${ }^{34}$

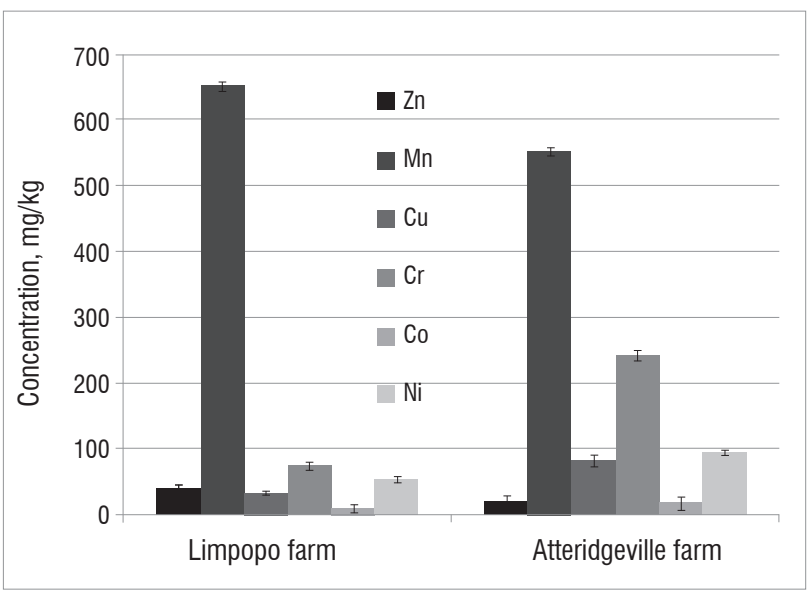

Figure 4: Average concentration of minor elements in soil samples from farms in the Limpopo and Atteridgeville. Results shown are means of triplicates; error bars represent \%RSD values.

The concentrations of the trace elements - $\mathrm{Cr}$, Cu, $\mathrm{Zn}$ and $\mathrm{Pb}-$ determined in this study were compared with standards from Germany, the UK and Canada. The concentration of $\mathrm{Cr}$ in the soil from the farm in Limpopo was lower $(80 \mathrm{mg} / \mathrm{kg})$ than the German standard $(200 \mathrm{mg} / \mathrm{kg})$ and similar to the UK $(60 \mathrm{mg} / \mathrm{kg})$ and Canadian $(85 \mathrm{mg} / \mathrm{kg})$ standards. However, the concentration of $\mathrm{Cr}$ in soil from the farm in Atteridgeville was the highest at about $240 \mathrm{mg} / \mathrm{kg}$. Higher concentrations of $\mathrm{Cr}$ in soil from the Atteridgeville farm could mean possible contamination of the soil by an anthropogenic source. However, it is difficult to pinpoint the source as there are no previous data on the soil at that site.

The concentration of $\mathrm{Zn}$ in the soil from the farm in Limpopo was $30 \mathrm{mg} / \mathrm{kg}$ and from the farm in Atteridgeville was $15 \mathrm{mg} / \mathrm{kg}$ - these concentrations are well within the German, UK and Canadian standards of $300 \mathrm{mg} / \mathrm{kg}$, $300 \mathrm{mg} / \mathrm{kg}$ and $400 \mathrm{mg} / \mathrm{kg}$, respectively. Pb concentrations in soils from the Limpopo and Atteridgeville farms were $120 \mathrm{mg} / \mathrm{kg}$ and $130 \mathrm{mg} / \mathrm{kg}$, respectively, while the German, UK and Canadian standards for $\mathrm{Pb}$ are $500 \mathrm{mg} / \mathrm{kg}, 100 \mathrm{mg} / \mathrm{kg}$ and $200 \mathrm{mg} / \mathrm{kg}$, respectively. The concentration of $\mathrm{Cu}$ in the soil from the Limpopo $(30 \mathrm{mg} / \mathrm{kg})$ was within the German, UK and Canadian standards of $50 \mathrm{mg} / \mathrm{kg}, 100 \mathrm{mg} / \mathrm{kg}$ and $100 \mathrm{mg} / \mathrm{kg}$, but the concentration of $\mathrm{Cu}$ in the soil from Atteridgeville exceeded the German standard at $80 \mathrm{mg} / \mathrm{kg}$.

\section{Metal content in moringa leaves and vegetable samples}

It is well known that the use of agrochemicals for the intensification of agriculture can result in the accumulation of heavy metals. We therefore analysed the metal content of the moringa leaves and flowers and some vegetables (spinach, cabbage, peas, broccoli and cauliflower). The concentrations of the major nutrients and trace elements are shown in Figures 5 and 6 , respectively. The concentrations in moringa of these metals were compared with those in the vegetables and related to soil content to determine if a correlation existed.

It can be seen in Figure 5 that moringa contained a higher concentration of $\mathrm{Ca}$ than did the vegetables. The results suggest that the older the plant, the higher the Ca concentration, perhaps as a result of a longer period of uptake. However, spinach, broccoli and cauliflower had higher concentrations of $\mathrm{K}$ than did moringa. Moringa contained more $\mathrm{Mg}$ (an average of $6000 \mathrm{mg} / \mathrm{kg}$ ) than the vegetables, except spinach 


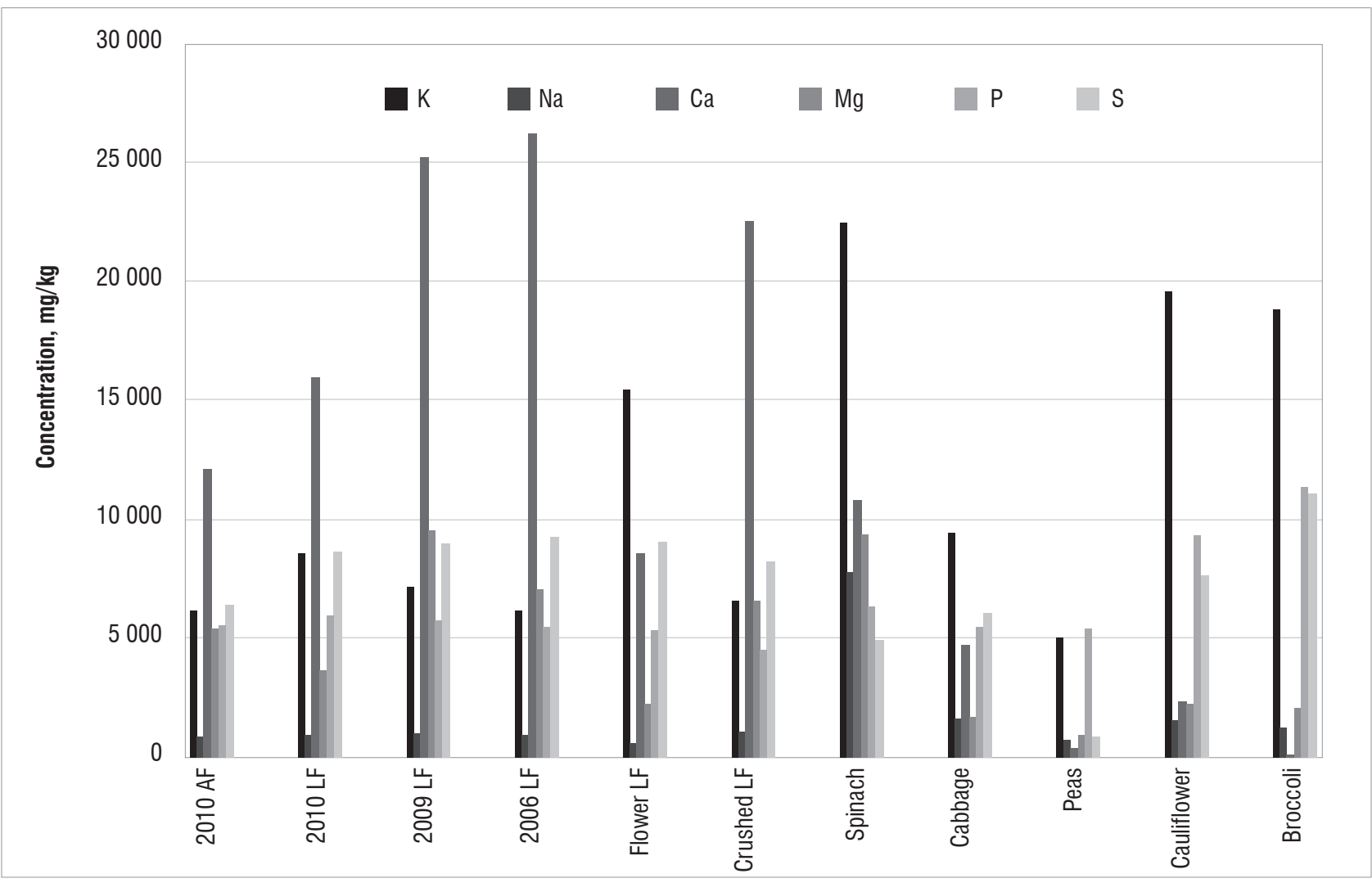

$A F$, farm in Atteridgeville; LF, farm in Limpopo.

Crushed LF refers to moringa leaves which were purchased in packets.

Figure 5: Concentration of major nutrient elements in moringa and selected vegetables.

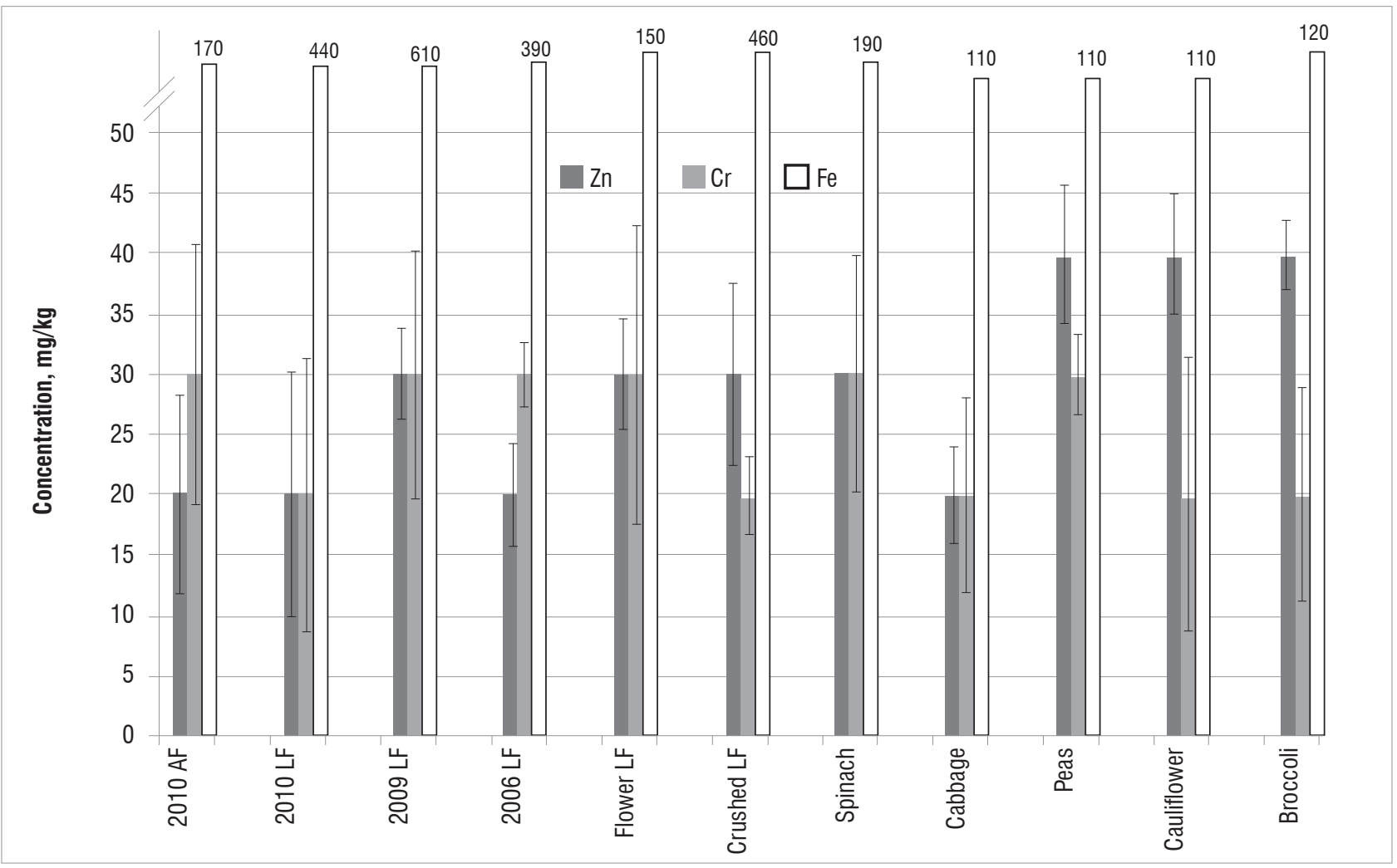

AF, farm in Atteridgeville; LF, farm in Limpopo.

Crushed LF refers to moringa leaves which were purchased in packets.

Values above the bars indicate the concentration of $\mathrm{Fe}$.

Figure 6: Concentration of trace nutrient elements in moringa and selected vegetables. Results shown are means of triplicates; error bars represent \%RSD values. 
(at $9000 \mathrm{mg} / \mathrm{kg}$ ). The concentrations of the other nutrients analysed were similar among the plants. Moringa is more comparable to spinach than the other vegetables, in terms of major nutrient concentrations. Other trace elements such as $\mathrm{Cd}, \mathrm{Cu}$ and $\mathrm{Pb}$ were not detected in the present study; the plants can be described as deficient in these metals. ${ }^{35}$

Results showing the $\mathrm{Cr}$ and $\mathrm{Zn}$ trace nutrient analyses are shown in Figure 6 . These values were interpreted using those reported by Pugh et al. ${ }^{35}$ (Table 3). Zn concentrations in moringa were in the range of $10-150 \mathrm{mg} /$ $\mathrm{kg}$, which is regarded as normal (Table 3). Therefore, the moringa plants investigated in this study are safe for human consumption as far as the level of trace elements is concerned. By comparing the levels of trace metals in the moringa leaves with those in the soils, we determined that the moringa plant is not able to absorb these trace metals from the soil. Hence the source of trace metals in the leaves might not be from the soil, ${ }^{23}$ but rather from other sources such as atmospheric deposition, and the concentrations may be influenced by the absorption capacities of the plants for heavy metals. ${ }^{36}$ Numerous environmental factors including wind velocity, temperature and moisture, and the nature of the vegetables (e.g. exposed surface areas of leaves, roots and fruit and whether the exposed parts are smooth or hairy) could influence metal uptake by plants. ${ }^{36}$ However, because only the leaves were investigated here, the accumulation by roots is not known. Nonetheless, if the roots did accumulate heavy metals, they are not transferring them to the leaves.

Table 3: Typical concentrations of heavy metals in plants at deficient, normal and phytotoxic levels

\begin{tabular}{|l|l|l|l|l|}
\hline \hline Level & \multicolumn{2}{l|}{ Concentration $(\mathrm{mg} / \mathrm{kg})$} & \\
\hline \hline & $\mathrm{Cd}$ & $\mathrm{Cu}$ & $\mathrm{Pb}$ & $\mathrm{Zn}$ \\
\hline Deficient & - & $<1-5$ & - & $<10$ \\
\hline Normal & $0.05-2$ & $3-30$ & $0.5-10$ & $10-150$ \\
\hline Phytotoxic & $5-700$ & $20-100$ & $30-300$ & $>100$ \\
\hline
\end{tabular}

Source: adapted from Pugh et al. ${ }^{35}$

Because of a relatively large abundance of Fe compared with the other minor nutrients (Figure 6), the Fe concentrations are given above the bars in Figure 6. Moringa contained more Fe than did the selected vegetables. Because of difficulties associated with the absorption of non-haem by the intestines, it is generally recommended that green leafy vegetables be consumed together with foods containing vitamin $\mathrm{C}$, such as orange juice, broccoli and tomato. ${ }^{37}$ However, in the case of moringa, which is high in both $\mathrm{Fe}$ and vitamin $\mathrm{C}$, co-consumption is not necessary.

\section{Conclusion}

The concentrations of heavy metals in soils in South Africa in this study were in the range of those published as maximum allowable concentrations in Germany, Canada and the UK. This finding implies that the soils in which the moringa trees are planted in the Limpopo and Atteridgeville are not polluted by heavy metals, and as such the moringa is fit for consumption. In addition, moringa does not accumulate metals in its leaves. On average, moringa leaves contained a higher concentration of mineral nutrients than locally sourced vegetables. Moringa leaves also contained substantial amounts of flavonols, justifying the use of moringa as a natural antioxidant.

\section{Acknowledgements}

This work was supported by funding from the National Research Foundation of South Africa and the Department of Science and Technology.

\section{Authors' contributions}

All authors contributed to the research; V.P. performed the experiments.

\section{References}

1. Booth FEM, Wickens GE. Non-timber uses of selected arid zone trees and shrubs in Africa. In: FAO Conservation Guide. Rome: Food and Agriculture Organization; 1988. p. 176.

2. Anwar F, Latif S, Ashraf M, Gilani AH. Moringa oleifera: A food plant with multiple medicinal uses. Phytother Res. 2007;21:17-25. http://dx.doi. org/10.1002/ptr.2023

3. Bhuptawat H, Folkard GK, Chaudhari S. Innovative physico-chemical treatment of wastewater incorporating Moringa oleifera seed coagulant. J Hazard Mater. 2007;142:477-482. http://dx.doi.org/10.1016/j.jhazmat.2006.08.044

4. Rashid U, Anwar F, Moser BR, Knothe G. Moringa oleifera oil: A possible source of biodiesel. Bioresour Technol. 2008;99:8175-8179. http://dx.doi. org/10.1016/j.biortech.2008.03.066

5. Siddhuraju P, Becker K. Antioxidant properties of various solvent extracts of total phenolic constituents from three different agroclimatic origins of drumstick tree (Moringa oleifera Lam.) leaves. J Agric Food Chem. 2003;51:2144-2155. http://dx.doi.org/10.1021/jf020444+

6. Caceres A, Saravia A, Rizzo S, Zabala L, Leon ED, Nave F. Pharmacologic properties of Moringa oleifera 2: Screening for antispasmodic, antiinflammatory and diuretic activity. J Ethnopharmacol. 1992;36:233-237. http://dx.doi.org/10.1016/0378-8741(92)90049-W

7. Bennett RN, Mellon FA, Foidl N, Pratt JH, Dupont MS, Perkins L, et al. Profiling glucosinolates and phenolics in vegetative and reproductive tissues of the multi-purpose trees Moringa oleifera L. (horseradish tree) and Moringa stenopetala L. J Agric Food Chem. 2003:51:3546-3553. http://dx.doi. org/10.1021/jf0211480

8. Fahey JW, Zalcmann AT, Talalay P. The chemical diversity and distribution of glucosinolates and isothiocyanates among plants. Phytochemistry. 2001;56:5-51. http://dx.doi.org/10.1016/S0031-9422(00)00316-2

9. Leuck M, Kunz H. Synthesis of active principles from the leaves of Moringa oleifera using S-pent-4-enyl thioglucosides. Carbohydr Res. 1998;312:33-44. http://dx.doi.org/10.1016/S0008-6215(98)00223-7

10. Pezzuto JM, Park EJ. Autooxidation and antioxidants. In: Swarbrick J, Boylan JC, editors. Encyclopedia of pharmaceuticals technology. 2nd ed. New York: Marcel Dekker Inc.; 2002. p. 97-113.

11. Ames BN, Shigenga MK, Hagen TM. Oxidants, antioxidants and degenerative diseases of aging. Proc Natl Acad Sci USA. 1993;90:7915-7922. http:// dx.doi.org/10.1073/pnas.90.17.7915

12. Razali I, Norhaya $H$, Norasimah AS. Determination of antioxidants in palm oil products by HPLC. Elaeis. 1997;9(1):25-31.

13. Fridovich I. The biology of oxygen radicals. Science. 1978;201:875-880. http://dx.doi.org/10.1126/science.210504

14. Soong YY, Barlow PJ. Antioxidant activity and phenolic content of selected fruit seeds. Food Chem. 2004;88:411-417. http://dx.doi.org/10.1016/j. foodchem.2004.02.003

15. Sun T, Ho CT. Antioxidant activities of buckwheat extracts. Food Chem. 2005;90:743-749. http://dx.doi.org/10.1016/j.foodchem.2004.04.035

16. Dillard CJ, German JB. Phytochemicals: Nutraceuticals and human health. J Sci Food Agric. 2000;80:1744-1756. http://dx.doi.org/10.1002/10970010(20000915)80:12<1744::AID-JSFA725>3.0.C0;2-W

17. Laandrault N, Pouchert P, Ravel P, Gase F, Cros G, Teissedro PL. Antioxidant activities and phenolic level of French wines from different varieties and vintages. J Agric Food Chem. 2001;49:3341-3343. http://dx.doi. org/10.1021/jf010128f

18. Larson RA. The antioxidants of higher plants. Phytochemistry. 1988;27:969-978. http://dx.doi.org/10.1016/0031-9422(88)80254-1

19. Iqbal S, Bhanger Ml. Effect of season and production location on antioxidant activity of Moringa oleifera leaves grown in Pakistan. J Food Comp Anal. 2006;19:544-551. http://dx.doi.org/10.1016/j.jfca.2005.05.001

20. Adriano DC. Trace elements in the terrestrial environment. New York: SpringerVerlag; 1986. http://dx.doi.org/10.1007/978-1-4757-1907-9

21. Kabata-Pendias A, Pendias H. Trace elements in soils and plants. 2nd ed. Boca Raton: CRC Press; 1992 
22. Boularbah A, Schwartz C, Bitton G, Aboudrar W, Ouhammou A, Morel JL. Heavy metal contamination from mining sites in South Morocco 2: Assessment of metal accumulation and toxicity in plants. Chemosphere. 2006;63:811-817. http://dx.doi.org/10.1016/j.chemosphere.2005.07.076

23. Olowoyo JO, Van Heerden E, Fischer JL, Baker C. Trace metals in soil and leaves of Jacaranda mimosifolia in Tshwane area, South Africa. Atmos Environ. 2010;44:1826-1830. http://dx.doi.org/10.1016/j.atmosenv.2010.01.048

24. Hashmi DS, Ismail S, Shaikh GH. Assessment of the level of trace metals in commonly edible vegetables locally available in the markets of Karachi city. Pak J Bot. 2007;39:747-751.

25. Cook JD, Dassenko SA, Lynch SR. Assessment of the role of nonheme-iron availability in iron balance. Am J Clin Nutr. 1991;54:717-722.

26. Naicker K, Cukrowska E, McCarthy TS. Acid mine drainage arising from gold mining activity in Johannesburg, South Africa and environs. Environ Pollut. 2003;22(1):29-40. http://dx.doi.org/10.1016/S0269-7491(02)00281-6

27. Sultana B, Anwar F. Flavonols (kaempeferol, quercetin, myricetin) contents of selected fruits, vegetables and medicinal plants. Food Chem. 2008;108:879-884. http://dx.doi.org/10.1016/j.foodchem.2007.11.053

28. Nöthlings U, Murphy SP, Wilkens LR, Henderson BE, Kolonel LN. Flavonols and pancreatic cancer risk: The multiethnic cohort study. Am J Epidemiol. 2007;166(8):924-931. http://dx.doi.org/10.1093/aje/kwm172
29. Anwar F, Ashraf M, Bhanger MI. Interprovenance variation in the composition of Moringa oleifera from Pakistan. J Am Oil Chemists Soc. 2005;82:45-51. http://dx.doi.org/10.1007/s11746-005-1041-1

30. Nicholls PH, Evans AA. Sorption of organic compounds by field soils. Part one: Acids. Pesticide Sci. 1991;33(3):319-330. http://dx.doi.org/10.1002/ ps. 2780330306

31. Palada MC, Chang LC. Suggested cultural practices for moringa. AVRDC International Cooperators' Guide. AVRDC; 2003. p. 1-5.

32. Krauskopf KB. Introduction to geochemistry. New York: NY McGraw Hill; 1967.

33. ZoBell CE. Studies on redox potential of marine sediments. AAPG Bulletin. 1946;30, doi: 10.1306/3D933808-16B1-11D7-8645000102C1865D.

34. Gonzalez RC, Gonzalez-Chavez MCA. Metal accumulation in wild plants surrounding mining wastes. Environ Pollut. 2006;144:84-92. http://dx.doi. org/10.1016/j.envpol.2006.01.006

35. Pugh RE, Dick DG, Fredeen AL. Heavy metal (Pb, Zn, Cd, Fe and Cu) contents of plant foliage near the Anvil Range Lead/Zinc mine, Faro, Yukon Territory. Ecotoxicol Environ Saf. 2002;52:273-279. http://dx.doi.org/10.1006/ eesa.2002.2201

36. Zurera G, Moreno R, Salmeron J, Pozo R. Heavy metal uptake from greenhouse border soils for edible vegetables. J Food Sci Agric.1989;49:307-314. http:// dx.doi.org/10.1002/jsfa.2740490307

37. Hurrell R, Egli I. Iron bioavailability and dietary reference values. Am J Clin Nutr. 2010;91(5):1461S-1467S. 